\title{
Histological analysis of the effects of a static magnetic field on bone healing process in rat femurs Edela Puricelli* $^{* 1}$, Lucienne M Ulbrich ${ }^{\dagger 2}$, Deise Ponzoni ${ }^{\dagger 2}$ and João Julio da Cunha Filho ${ }^{\dagger 2}$
}

\author{
Address: ${ }^{1}$ Oral and Maxillofacial Surgery Unit, Hospital de Clinicas de P.A., School of Dentistry, UFRGS, Porto Alegre, RS, Brazil and ${ }^{2}$ Dept. of Oral \\ Maxillofacial Surgery, School of Dentistry, UFRGS, Porto Alegre, RS, Brazil \\ Email: Edela Puricelli* - epuricelli@uol.com.br; Lucienne M Ulbrich - Imulbrich@yahoo.com; Deise Ponzoni - deponzoni@yahoo.com; \\ João Julio da Cunha Filho - jjulio.voy@terra.com.br \\ * Corresponding author †Equal contributors
}

Published: 24 November 2006

Head \& Face Medicine 2006, 2:43 doi:10.1186/1746-160X-2-43

This article is available from: http://www.head-face-med.com/content/2/1/43

(C) 2006 Puricelli et al; licensee BioMed Central Ltd.

This is an Open Access article distributed under the terms of the Creative Commons Attribution License (http://creativecommons.org/licenses/by/2.0), which permits unrestricted use, distribution, and reproduction in any medium, provided the original work is properly cited.
Received: 15 February 2006

Accepted: 24 November 2006

\begin{abstract}
Background: The aim of this study was to investigate, in vivo, the quality of bone healing under the effect of a static magnetic field, arranged inside the body.

Methods: A metallic device was developed, consisting of two stainless steel washers attached to the bone structure with titanium screws. Twenty-one Wistar rats (Rattus novergicus albinus) were used in this randomized experimental study. Each experimental group had five rats, and two animals were included as control for each of the groups. A pair of metal device was attached to the left femur of each animal, lightly touching a surgically created bone cavity. In the experimental groups, washers were placed in that way that they allowed mutual attraction forces. In the control group, surgery was performed but washers, screws or instruments were not magnetized. The animals were sacrificed 15, 45 and 60 days later, and the samples were submitted to histological analysis.

Results: On days 15 and 45 after the surgical procedure, bone healing was more effective in the experimental group as compared to control animals. Sixty days after the surgical procedure, marked bone neoformation was observed in the test group, suggesting the existence of continued magnetic stimulation during the experiment.
\end{abstract}

Conclusion: The magnetic stainless steel device, buried in the bone, in vivo, resulted in increased efficiency of the experimental bone healing process.

\section{Background}

Bone neoformation is of primary importance for the success of dental clinical-surgical treatments. Much attention has been given to the research of new strategies to improve oral maxillofacial surgical techniques, as well as on the knowledge and application of biomaterials [1] an their possible chemical and physical consequences on the patients.
Electromagnetic fields have been used for the stimulation of bone neoformation processes. Their effects are observed in the treatment of osteoporosis, osteonecrosis, osteotomized areas, integration of bone grafts and posttraumatic pseudarthrosis [2]. Several cell functions were also shown to be influenced by electromagnetic fields $[3,4]$. Electromagnetism affects osteogenesis through mechanisms such as neovascularization, collagen produc- 
tion, proliferation and differentiation of osteogenic cells, and the maintenance of the molecular structure of the extracellular matrix [5-7].

The objective of the present study is to contribute to the understanding of processes involved in the response of bone to electromagnetic fields, by evaluation of cortical and trabecular bone neoformation. Cell stimulation was induced by static, in vivo buried magnetic fields.

\section{Methods}

Twenty-one male Wistar rats (Rattus novergicus albinus) were used in this randomized experimental study, aiming at the use of permanent magnetic fields buried in vivo. The animals were six-months old and weighed in average 450 grams. They were divided into three experimental and control groups, which were analyzed on days 15, 45 and 60 after beginning of the experiment.

The metal devices consisted of commercially pure martensitic stainless steel washers and titanium screws. The screws measured $1.0 \mathrm{~mm}$ in diameter, $0.5 \mathrm{~mm}$ in thread pitch and $2.0 \mathrm{~mm}$ in length. The pre-made magnetized washers were $3.0 \mathrm{~mm}$ in outer diameter, $1.5 \mathrm{~mm}$ in core diameter and $0.5 \mathrm{~mm}$ in thick. They were held over a 60 $\mathrm{mm} \times 12 \mathrm{~mm} \times 5 \mathrm{~mm}$ magnet during the sterilization process and surgery. The magnetic field was 41 Gauss (G). Calculations were performed at the Electromagnetism Laboratory, Physics Institute from Universidade Federal do Rio Grande do Sul.

The animals were anesthetized by intraperiotoneal injection of sodium tiopenthal in a dose of $25 \mathrm{mg} / \mathrm{kg}$ body weight and local infiltration of $3 \%$ prilocaine with felypressin.

After reaching the medial portion of the left femur diaphisis, a surgical bone cavity was produced with a trephine $\left(\right.$ PROMM $^{\circledast}$, Comércio de Implantes Cirúrgicos Ltda. Porto Alegre, RS, Brazil) measuring $2.0 \mathrm{~mm}$ diameter active region, with low rotation and constant irrigation. Two holes were drilled with a drill guide $\left(\right.$ PROMM $\left.^{\circledast}\right) 1.0$ $\mathrm{mm}$ away from the osteotomized border, one of them proximal and the other one distal to the surgical bone cavity. The washers were attached to the bone structure with titanium screws (Figure 1). A magnetic field was created in animals of the test groups, by placing up the north and south poles of the distal and proximal washers. In control animals, surgery included non-magnetized instruments, washers and screws.

The placement and stability of implants were confirmed by radiographic examination at the end of the experiments. Samples were submitted to longitudinal sectioning of the femur, which allowed simultaneous examination of the surgical cavity between the screw holes. The samples were prepared in hematoxylin and eosin stain (HE) for histological analysis.

\section{Results}

On day 15, extensive trabecular formation with marked osteoblastic activity was seen on the cortical marginal zone of samples from animals of the control group, beginning in the endosteum close to the osteotomized cortical surface. On the external surface, its predominantly horizontal and flat direction maintained continuity and shape of the remaining cortical levels. Trabecular proliferation was also apparent in a centripetal direction relative to the surgical cavity. Medullary spaces showed connective tissue which was richly populated with cells and intense osteoblastic activity (Figure 2). In animals from the test group, trabecular formations presented a marginal centripetal direction relative to the magnetic field. The cortical wall on the osteotomized area presented a tendency to convexity, escaping from the horizontal outer border where the remaining cortical walls were located (Figure 3). Regular bone formation was observed following the limits of the magnetic washer. Medullary spaces were filled with numerous trabecular bone formations, showing a tendency for more abundant vertical growth. Rich hematopoietic tissue, with marked cell activity, could also be observed.

On day 45, little activity was observed in the cortical zone of samples derived from the control group, which maintained convexity and showed predominant lamellar deposition. Areas limited by the washers showed fibrous tissue associated to osteoclastic activity. Medullary space was extensively invaded by bone trabecules and vascularized hematopoietic tissue (Figure 4). In the test group, the bone structure showed well organized areas of trabecular bone interspersed with medullary tissue. Blood vessels, adipose degeneration and osteoclastic activity were observed in medullary spaces, suggesting bone remodelling (Figure 5).

On day 60, active remodelling of the surgical cavity was apparent in samples from the control group, with normal cortical bone structures, trabecular spaces and hematopoietic tissue. Important thickening of the fibrous connective tissue was observed. This fibrous capsule is possibly due to an inflammatory reaction to the foreign body represented by the buried metallic device (Figure 6). In specimens from the test group, centrifugal growth, approximately symmetrical and bilateral in relation to the wound borders and reproducing the washers layout, was seen (Figure 7). Bone formation, surpassing the cortical level, showed recovery with normal characteristics. Distinct alterations were no longer present when the original 


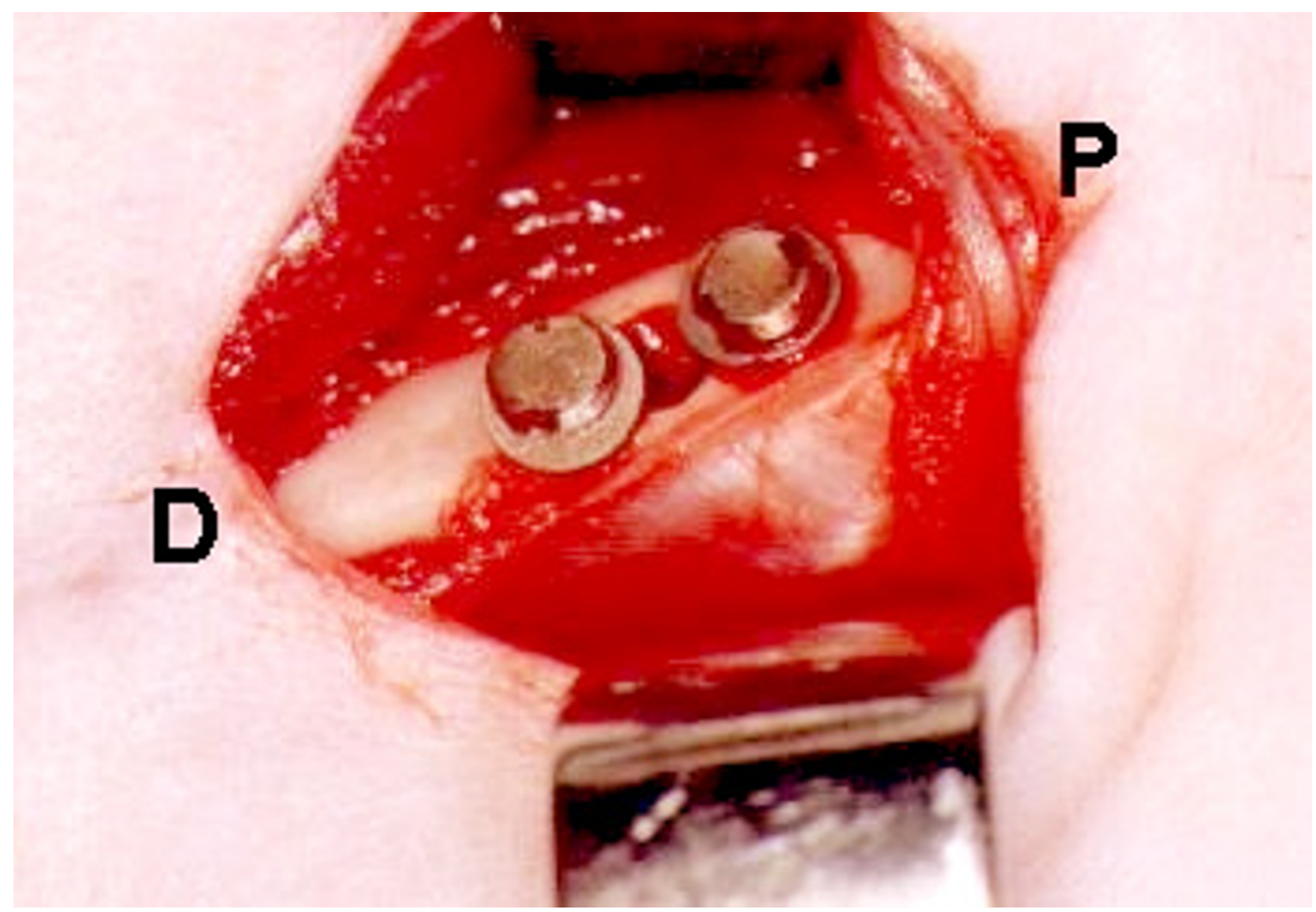

Figure I

Distribution of screws and washers, outlining the borders of the surgical bone cavity. A distance of I.3 mm separates the washers over the surgical cavity, corresponding to the area where the magnetic field operates. P and D mark, respectively, the proximal and distal regions of the left femur.

and healed bone were compared, at the level of the medullary channel.

\section{Discussion}

As in many other studies reported, rat was also used as a model in this study $[1,6,8-10]$. The advantages include easy manipulation, maintenance and adaptation to the objectives of the study. Other animals have been used, such as rabbits $[7,11,12]$ or dogs $[13]$.

This experimental study was based on investigations reported by Brighton (apud Christian) [14]; Burkitt, Young and Heath [15]; Hunter (apud Christian) [14]; and Lane and Davis (apud Christian) [14]. The surgically prepared bone cavity presented only one ruptured cortical, maintaining thus the reproducibility of a fixed fracture [16].
The metallic washers were attached to the bone structure with titanium screws. Biocompatibility of titanium with the spongeous medullary area has already been shown by Veeck, Puricelli and Souza [1]. Due to technical difficulties, the stainless steel washers were not protected against corrosion, differing thus from those used by Lemons and Natiella [17]. Martensitic stainless steel relates to the classification described by Chiaverini [18]. The need for externally adapted electric currents was avoided by the generation of a magnetic field through buried magnets, which resulted in a constant field with no need for reactivation during the experimental period.

A 41 G magnetic field was used, significantly higher than that of previously reported studies such as those of Grace, Revell and Brookes [5]; Matsumoto et al. [7]; Fini et al. [11]; Aaron, Wang and Ciombor [9]; and Ciombor et al. 


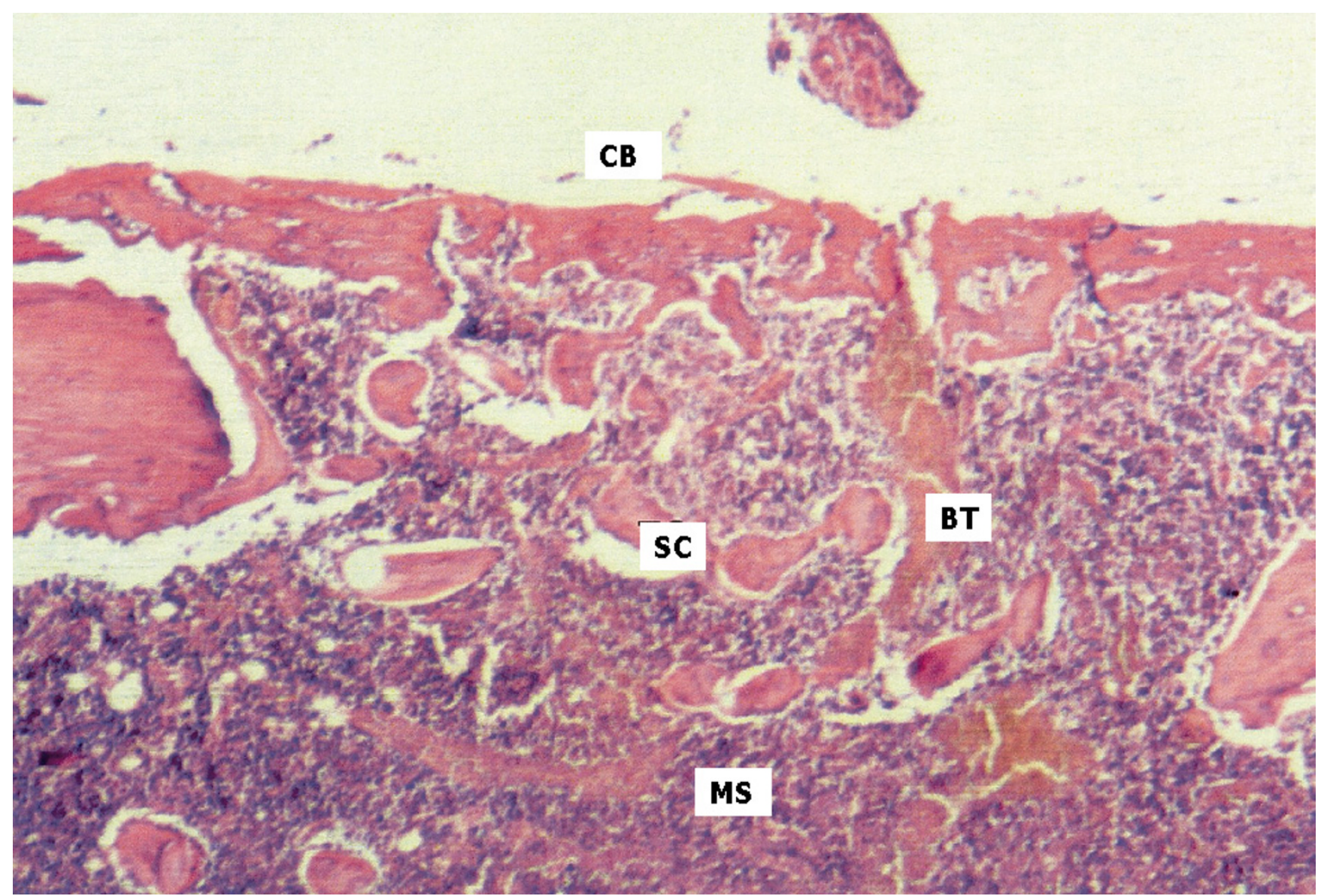

Figure 2

Control group, day I5. Surgical cavity (SC) limited on the upper side by cortical neoformation linearly continuous to borders (CB). Beginning of bone trabeculae in centripetal direction (BT). Medullary spaces showing connective tissue of great cellularity (MS). (HE 40x).

[10], in which intensities of 12 G, 2 G, 16 G, 16 G and 16 $\mathrm{G}$ were employed respectively. The expressive difference in charge was due to lack of calibration information in literature reports, and to the novelty represented by devices which keep an active, isolated field with no possible reactivation.

Different in vitro and in vivo experimental systems have been used for the investigation of electric fields effects in vital tissues. Bodamyali et al. [19] and Ishisaka et al. [3] described the use of weak magnets for in vitro cell stimulation, but observed little activity in this system. In vivo studies were performed by Grace, Revell and Brookes [6]; Matsumoto et al. [7]; Fini et al. [11]; Aaron, Wang and Ciombor [9]; Ciombor et al. [10] and Inoue et al. [13], with daily application of electromagnetic fields during 2 , $8,6,1,8$ and 8 hours respectively. Experiments were con- ducted during periods between 2 days and 8 weeks, and the studies were characterized by the use of an electromagnetic field with continuous stimulation.

According to Halliday et al. [20], the electric neutrality of a body is modified when it is submitted to a magnetic field. Reports by Oishi and Onesti [2] and Teló [4] suggest that cell electronegativity at bone fractures and after cancer treatment should be regarded as a possible indication of electric modifications on the local wound.

The extensive trabecular formation beginning in the endosteum, histologically observed in the surgical bone cavity in samples from the test groups as early as 15 days later, suggests that the magnetic field stimulates bone healing. 


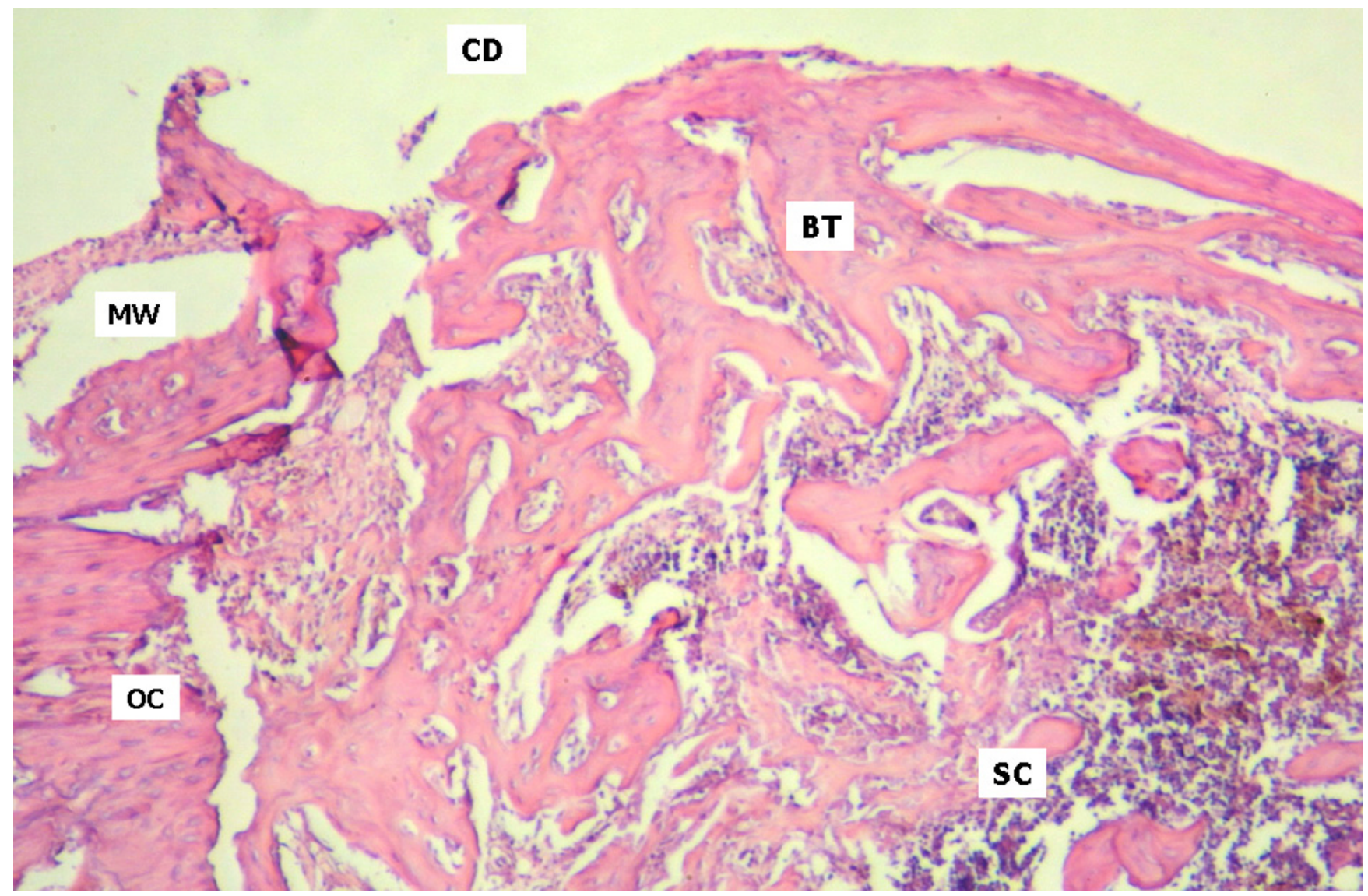

\section{Figure 3}

Test group, day I5. Surgical cavity (SC) with extensive centrifugal trabecular formation. Beginning of bone trabeculae in centrifugal direction (BT, CD). In (OC), osteotomized cortical bone marks the border of the cavity, supporting the magnetized washer (MW) (HE 40x).

On day 45, neoformed bone was rather similar to the surrounding bone tissue in test and control groups, showing the presence of a first intention healing process as stated by Lane and Danis (apud Christian) [14]. In the test group, however, stronger neovascularization as well as osteoclastic and bone remodelling activities were observed.

On day 60 , besides marked external configuration of the magnetic washers with cortical bone, the establishment of bone projections beyond the external border of the previously osteotomized cortical was observed. These results suggest that the magnetic field was active during all the experimental period. Even though they cannot be strictly compared to the studies of Grace, Revell and Brookes [6]; Matsumoto et al. [7]; Fini et al. [11]; and Fredericks et al. [12], since these authors used intermittent electromag- netic fields, the results of the present work agree with the accelerated bone neoformation reported.

The histological observation of hematopoietic activity in the bone marrow is an important result. Urist, Delange and Finermann [21] and Grace, Revell and Brookes [6] suggested that cartilage formation is due to a shortage of blood supply. The results of the present study, with in vivo observations during a period of 60 days, show that blood supply to the region was not impaired, but on the contrary was stimulated, which may explain the absence of cartilage formation during the healing process.

The results of the present experimental work indicate that further studies are needed for the detailed analysis of the in vivo activity and best intensity of magnetic stimulation on healing bone tissue. 


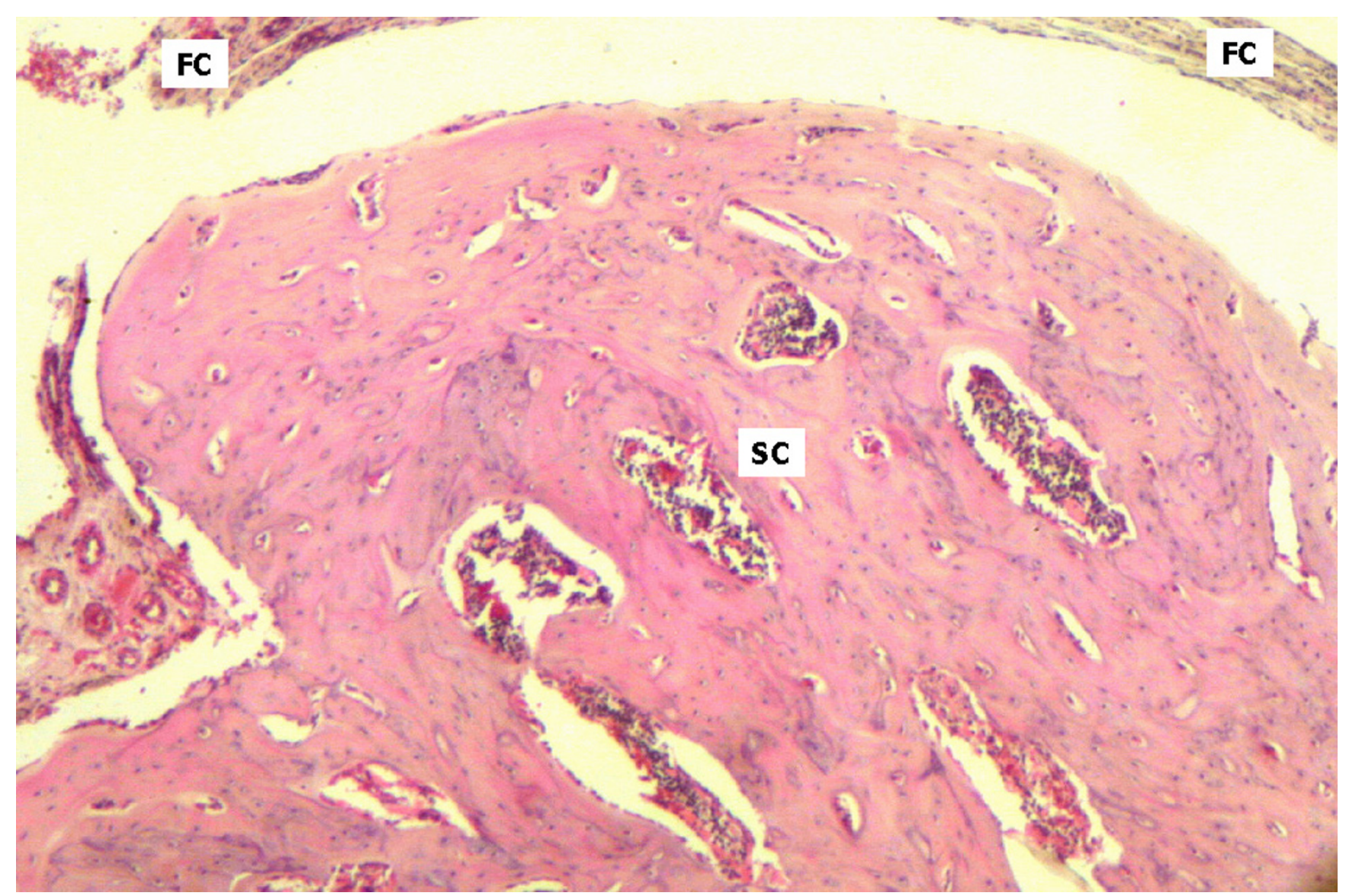

\section{Figure 4}

Control group, day 45. Surgical cavity (SC) with mature bone tissue, blood vessels and areas of internal remodelling. Fibrous capsules (FC) can be observed on the upper and lateral regions of the slide (HE 40x).

\section{Conclusion}

The experimental approach used in this study allows the following conclusions:

1. The magnetized stainless steel material used in these studies is able to affect the bone healing process;

2. The comparison of test and control groups indicates that bone healing was accelerated by the effect of magnetic fields in all the conditions analyzed;

3. The marked configuration of a bone outline involving the metallic devices in the test group, observed until the end of the experimental period, suggests that the magnetic field exerted a constant local activity on the surgical wound.

\section{Competing interests}

The author(s) declare that they have no competing interests.

\section{Authors' contributions}

EP suggested the original idea for the study; initiated the investigations leading to these results; wrote the protocols for the study and for the Research and Ethics in Health Committee; participated in discussions on the undertaking of the study; conceived, designed, and supervised the study; interpreted the data; reviewed all iterations of the paper. LMU developed the dissertation on which this work is based; participated in discussions on the undertaking of the study, supervised and participated in obtaining the results, interpreted the data, reviewed the paper for content, and reviewed and contributed to the writing of 


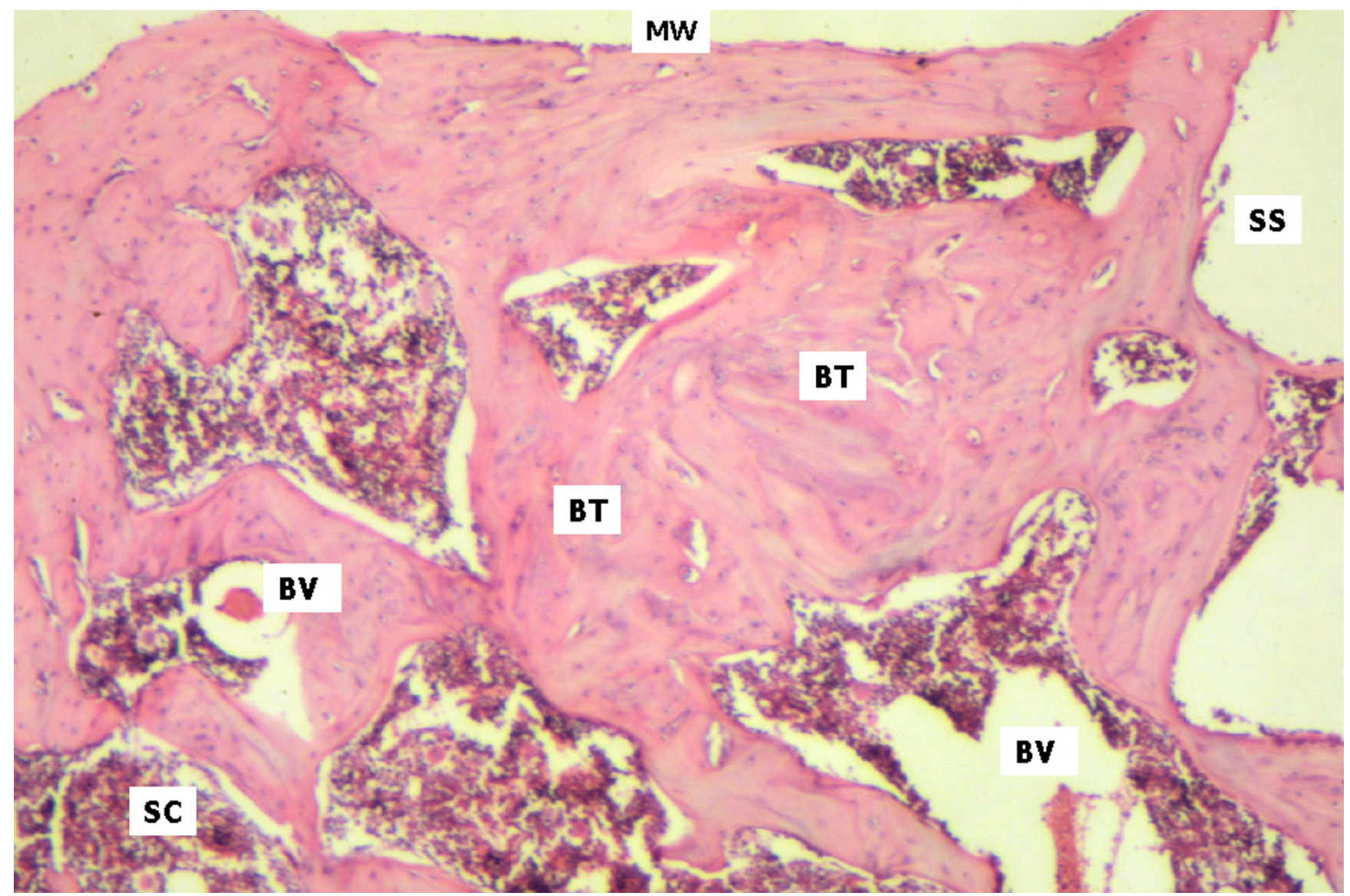

Figure 5

Test group, day 45. Surgical cavity (SC) with mature cortical and trabecular bone tissue characterized by lamellar structure. Blood vessels (BV) and areas of internal remodelling can be seen. Bone trabeculae remodeling (BT). Screw Space (SS). The neoformed area and the surrounding bone tissue (MW) show similar patterns (HE 40x).

all iterations of the paper. DP collaborated with laboratory experimental procedures and observation of animal bioethics guidelines; reviewed and contributed to the writing of all iterations of the paper, including the final version of the manuscript. JJCF participated in the analysis of results and implementation of material and other conditions for development of the project. All authors approved the final report.

\section{Acknowledgements}

We would like to thank Prof. Dr. Paulo Pureur Neto (Physics Institute, UFRGS), Marcel Fasolo de Paris (Oral and Maxillofacial Surgeon, Hospital Moinhos de Vento) and Isabel Regina Pucci (Manager, Instituto Puricelli \& Associados).

This study is in accordance with the guidelines for animal research established by the State Code for Animal Protection and Normative Rule 04/97 from the Research and Ethics in Health Committee/GPPG/HCPA.

\section{References}

I. Veeck EB, Puricelli E, Souza MAL: Análise do comportamento do osso e da medula hemopoética em relação a implantes de titânio e hidroxiapatita: estudo experimental em fêmur de rato. Odonto Ciência 1995, 10:235-291.

2. Oishi M, Onesti ST: Electrical Bone Graft Stimulation for Spinal Fusion: A Review. Neurosurgery 2000, 47: I04I-1056.

3. Ishisaka R, Kanno T, Inai Y, Nakahara H, Akiyama J, Yoshioka T, Utsumi K: Effects of a magnetic field on the various functions of subcellular organelles and cells. Pathophysiology 2000, 7:149-152.

4. Teló $M$, et al.: $\mathbf{O}$ uso da corrente elétrica no tratamento do câncer. Edited by: Teló M et al. Porto Alegre: Edipucrs; 2004.

5. Aaron RK, Ciombor DM: Therapeutic Effects of Electromagnetic Fields in the Stimulation of Connective Tissue Repair. J Cell Biochem 1993, 52:42-46.

6. Grace KL, Revell WJ, Brookes M: The Effects of Pulsed Electromagnetism on Fresh Fracture Healing: Osteochondral Repair in the Rat Femoral Groove. Orthopedics 1998, 21:297-302.

7. Matsumoto H, Ochi M, Abiko Y, Hirose Y, Kaku T, Sakaguchi K: Pulsed Electromagnetic Fields Promote Bone Formation Around Dental Implants Inserted into the Femur of Rabbits. Clin Oral Implants Res 2000, I I:354-360. 


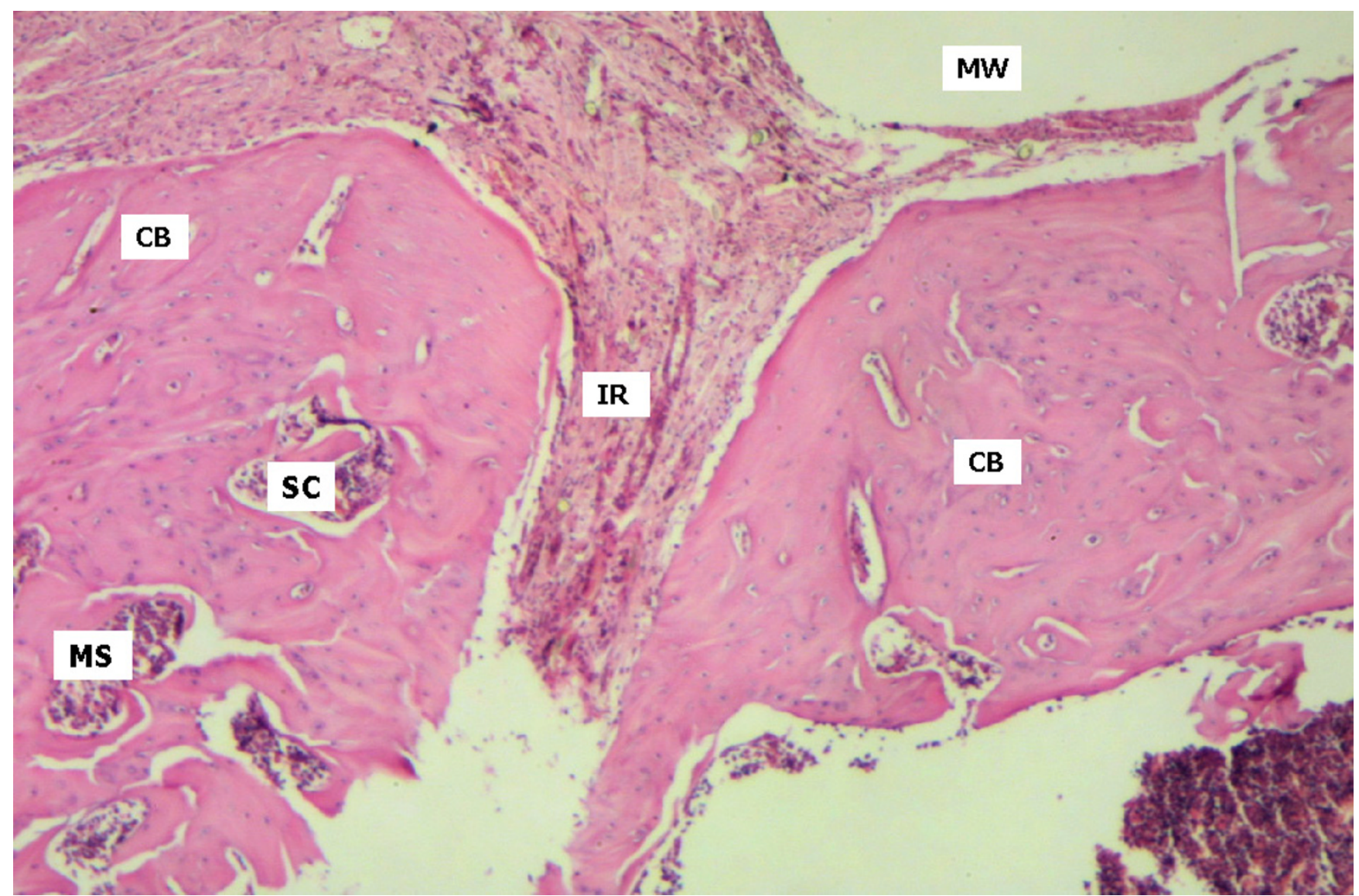

\section{Figure 6}

Control group, day 60 . Surgical cavity (SC) covered by neoformed cortical bone in remodelling with similar process in the femur residual cortical. Inflammatory response to a foreign body (IR) is apparent. Medullary spaces (MS). Cortical Bone (CB). Space corresponding to the washer (MW) (HE 40x).

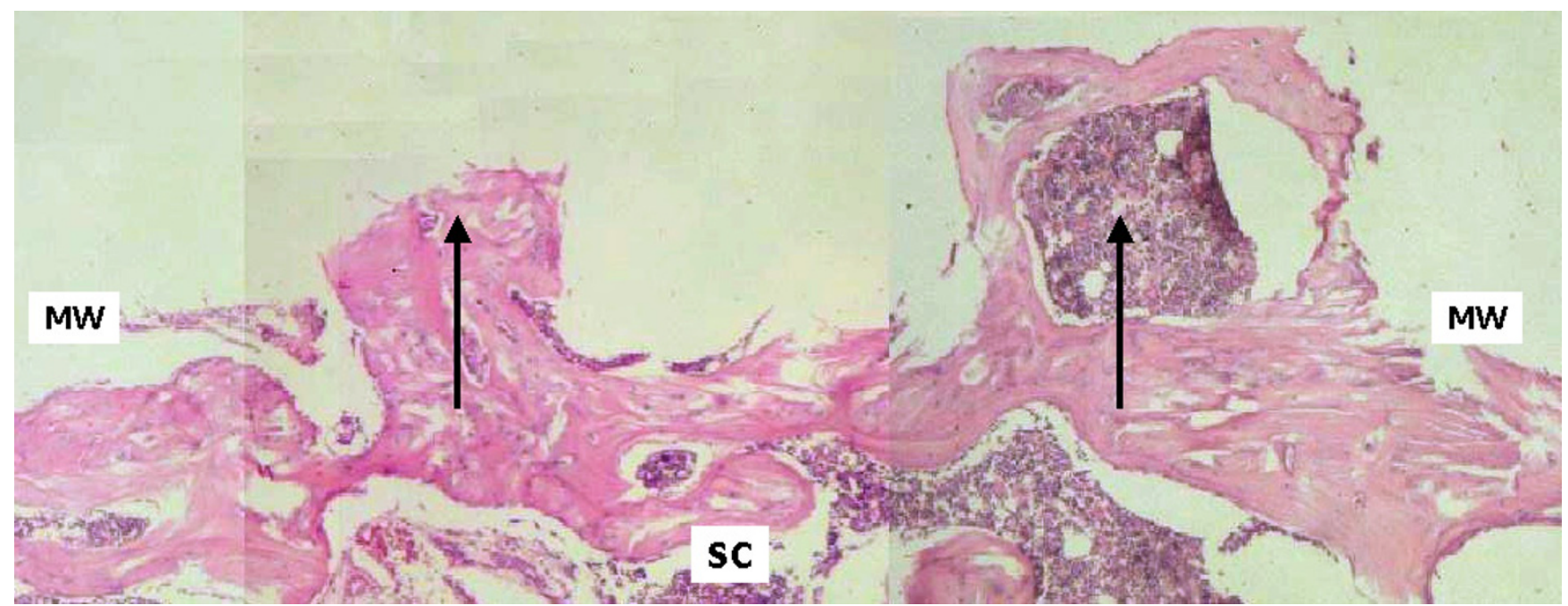

Figure 7

Test group, day 60. Photograph showing the surgical cavity sequence (SC). Centrifugal growth ( $\uparrow$ ), limiting the space corresponding to the magnetized washers are observed $(\mathrm{MW})$. Bone remodelling with normal histological patterns, going beyond the cortical external border, is observed (HE 40x). 
8. Nagai $N$, Inoue $M$, Ishiwari $Y$, Nagatsuka $H$, Tsujigiwa $H$, Nakano $K$, Nagaoka N: Age and Magnetic Effects on Ectopic Bone Formation Induced by Purified Bone Morphogenetic Protein. Pathophysiology 2000, 7:107-1/4.

9. Aaron RK, Wang S, Ciombor DM: Upregulation of Basal TGFbeta I Levels by EMF Coincident with Chondrogenesis: Implications for Skeletal Repair and Tissue Engineering. J Orthop Res 2002, 20:233-240.

10. Ciombor DM, Lester G, Aaron RK, Neame P, Caterson B: Low Frequency EMF Regulates Chondrocyte Differentiation and Expression of Matrix Proteins. J Orthop Res 2002, 20:40-50.

I I. Fini M, Cadossi R, Cane V, Cavani F, Giavaresi G, Krajewski A, Martini L, Aldini NN, Ravaglioli A, Rimondini L, Torricelli P, Giardino R: The Effect of Pulsed Electromagnetic Fields on the Osteointegration of Hydroxyapatite Implants in Cancellous Bone: A Morphologic and Microstructural In Vivo Study. J Orthop Res 2002, 20:756-763.

12. Fredericks DC, Nepola JV, Baker JT, Abbott J, Simon B: Effect of Pulsed Electromagnetic Field Stimulation on Distraction Osteogenesis in the Rabbit Tibial Leg Lengthening Model. J Pediatr Orthop 2003, 23:478-483.

13. Inoue N, Ohnishi I, Chen D, Deitz LW, Schwardt JD, Chao EY: Effect of Pulsed Electromagnetic Fields (PEMF) on Late-phase Osteotomy Gap Healing in a Canine Tibial Model. J Orthop Res 2002, 20:106-II4.

14. Christian CA: General Principles of Fracture Treatment. In Campbell's Operative Orthopaedics Volume 3. 9th edition. Edited by: Canale ST, Daugherty K, Jones L. St. Louis: Mosby; 1996: 1993-204I.

15. Burkitt HG, Young B, Heath JW: Wheater Histologia Funcional. 3rd edition. Rio de Janeiro: Guanabara Koogan; 1994.

16. Feinberg SE, Steinberg B, Helman Jl: Healing of Traumatic Injuries. In Oral and Maxillofacial Trauma Volume I. Edited by: Fonseca RJ, Walker RV. Philadelphia: Saunders; 1997:13-57.

17. Lemons J, Natiella J: Biomaterials, Biocompatibility, and PeriImplant Considerations. Dent Clin North Am 1986, 30:3-23.

18. Chiaverini V: Aços Resistentes à Corrosão. In Aços e Ferros Fundidos 5th edition. São Paulo: Associação Brasileira de Metais; 1982:322-357.

19. Bodamyali T, Bhatt B, Hughes FJ, Winrow VR, Kanczler JM, Simon B, Abbott J, Blake DR, Stevens CR: Pulsed Electromagnetic Fields Simultaneously Induce Osteogenesis and Upregulate Transcription. Biochem Biophys Res Commun 1998, 250:458-46 I.

20. Halliday, et al.: Eletromagnetismo. In Fundamentos de Física Volume 3. 3rd edition. Edited by: Halliday et al. Rio de Janeiro: Livros Técnicos e Científicos; 1994.

21. Urist MR, Delande RJ, Finerman GAM: Bone Cell Differentiation and Growth Factors. Science 1983, 220:680-686.

\section{Publish with Bio Med Central and every scientist can read your work free of charge}

"BioMed Central will be the most significant development for disseminating the results of biomedical research in our lifetime. "

Sir Paul Nurse, Cancer Research UK

Your research papers will be:

- available free of charge to the entire biomedical community

- peer reviewed and published immediately upon acceptance

- cited in PubMed and archived on PubMed Central

- yours - you keep the copyright

Submit your manuscript here:

http://www.biomedcentral.com/info/publishing_adv.asp
BioMedcentral 